\title{
Efek Aplikasi Jamur Parasit Nematoda G. rostochiensis Terhadap Tinggi dan Berat Kering Tajuk serta Serapan P dan K Tanaman Kentang
}

\author{
Marthin Kalay ${ }^{1}$, Sadeli Natasasmita ${ }^{2}$, Tarkus Suganda ${ }^{2}$ dan Tualar Simarmata ${ }^{3}$ \\ ${ }^{1}$ Fakultas Pertanian Universitas Pattimura, Kampus Poka, Ambon 97233 \\ ${ }^{2}$ Fakultas Pertanian Universitas Padjadjaran \\ Jalan Raya Jatinangor Km. 21 Bandung 40600 \\ Korespondensi: marthinkalay@yahoo.com
}

\begin{abstract}
Globodera rostochiensis (Woll) is obligate plant-parasitic nematodes that suppress potato growth in tropical region as well as in subtropical one. The mechanisms by which PCN cause the diseases is cincitium formation which hamper nutrient uptake from soil by plant roots. A Green house experiment has been done to verify the ability of PCN-parasitic fungus for increasing growth and uptake of macronutrient phosphorous $(\mathrm{P})$ and potassium $(\mathrm{K})$ by potatoes grown in soil infested by NSK cysts. Results showed that inoculation of Fusarium oxysporum TR1, F. solani TR2, F. oxysporum KT1, F. chlamydosporum KT2, F. oxysporum SM1, Phaecilomyces lilacinus SM3 dan $F$. chlamydosporum SM4 on growth media infested by cysts of $G$. rostochiensis, clearly increased shoot dry weight as well as $\mathrm{P}$ and $\mathrm{K}$ uptake by the shoots. These parasitic fungus could be used as biological agents to control PCN.
\end{abstract}

Key words: Parsitic fungi, Potato Cysts Nematode, Nutrient uptake.

\begin{abstract}
ABSTRAK
Globodera rostochiensis (Woll) adalah nematoda sista kuning (NSK) pengganggu tanaman yang berbahaya pada tanaman kentang baik di daerah tropis maupun sub tropis. Mekanisme NSK untuk menyebabkan penyakit adalah pembentukan sinsitium yang menghambat serapan unsur hara dari tanah oleh akar tanaman. Penelitian rumah kaca ini dilakukan untuk menguji kemampuan jamur parasitik NSK dalam meningkatkan pertumbuhan dan serapan unsur hara makro fosfor $(\mathrm{P})$ dan kalium $(\mathrm{K})$ tanaman kentang yang ditanam di tanah diinfestasi sista NSK. Percobaan rumah kaca dirancang dalam Rancangan Acak Kelompok yang menguji tujuh spesies jamur antagonis yang diisolasi dari sista NSK. Hasil percobaan menunjukkan bahwa inokulasi Fusarium oxysporum TR1, $F$. solani TR2, $F$. oxysporum KT1, $F$. chlamydosporum KT2, F. oxysporum SM1, Phaecilomyces lilacinus SM3 dan $F$. chlamydosporum SM4 pada media tanam yang terinfestasi sista G. rostochiensis, dengan nyata meningkatkan bobot kering tajuk serta serapan $\mathrm{P}$ dan $\mathrm{K}$ pada daun kentang. Jamur antagonis ini berpotensi untuk digunakan sebagai agen hayati pengendali NSK.
\end{abstract}

Kata kunci: Jamur parasitik, Nematoda sista kunign, Penyerapan unsur hara.

\section{PENDAHULUAN}

Salah satu organism penganggu tanaman (OPT) pada kentang (Solanum tuberosum L.) adalah nematoda sista kentang (Potato Cyst Nematode, PCN) Globodera rostochiensis (Woll.) dan G. pallida Stone
(Turner dan Evans, 1998). Nematoda ini ditemukan di berbagai negara produsen kentang di daerah tropis dan sub tropis, dan mampu menurunkan produksi kentang sampai $30 \%$ di Peru, lebih dari $58 \%$ di Bolivia (IPC, 2002), $64 \%$ di Inggris (Evans et al., 2003), dan $80 \%$ di daerah tropis dengan tingkat 
infestasi inokulum tinggi dan dengan penanaman kentang secara terus-menerus (Jatala \& Bridge, 1995). Di Malang serangan G. rostochiensis menurunkan produksi kentang dari 16 ton ha $^{-1}$ menjadi 4,7 - 9,3 ton ha ${ }^{-1}$ (Daryanto, 2003). Menurut Lisnawita (2007), pada tahun 2005 telah ditemukan G. pallida di daerah pertanaman kentang di Dieng Kabupaten Banjarnegara Propinsi Jawa Tengah.

Menghilangkan nematoda dari tanah yang telah terinfeksi merupakan sesuatu hal yang tidak mungkin untuk dilakukan. Usaha yang dapat dilakukan adalah mengendalikan populasi sampai pada tingkat yang tidak merugikan. Dalam sistem sistem pengendalian hama terpadu (PHT), pengendalian OPT dilaksanakan dengan memadukan satu atau lebih teknik pengendalian yang dikembangkan dalam satu kesatuan.

Pengendalian hayati dengan memanfaatkan mikroorganisme antagonis penting untuk dikembangkan, mengingat pengendalian kimiawi yang selama ini sering digunakan dapat menurunkan kualitas tanah, meningkatkan tingkat polusi air tanah dan perairan (Sanchesz-Bayo et al., 2002). Di luar negeri, pemanfaatan jamur terbukti efektif mengendalikan G. rostochiensis. Jaffe et al. (1998) mengemukakan bahwa jamur Cylindrocarpon destruktans, Acremonium strictus dan Fusarium oxysporium mampu menghancurkan sista dan telur G. rostochiensis. Di Inggris, pengendalian nematoda sista kentang dilakukan dengan memanfaatkan jamur Paecilomyces lilacinus dan Verticillium chlamydosporium (DAFFA, 2003). Hasil penelitian Kalay (2008) menunjukkan bahwa jamur Fusarium oxysporum TR1, F. solani TR2, F. oxysporum KT1, $F$. chlamydosporum KT2, $F$. oxysporum SM1, Paecilomyces lilacinus SM3, dan $F$. chlamydosporum SM4 dapat mengendalikan nematoda $G$. rostochiensis secara in vitro.

Menurut Semangun, (2000), jamur dari genus Fusarium diketahui juga merupakan jamur patogen tumbuhan seperti penyakit layu pada tomat dan busuk kering pada kentang. Sebuhungan dengan hasil-hasil penelitian tersebut di atas, maka dilakukan pengujian kemampuan ke tujuh jenis jamur tersebut terhadap pertumbuhan tanaman kentang di rumah kaca.

\section{BAHAN DAN METODE}

Percobaan ini dilakukan di rumah kaca Pusat Penelitian Teh dan Kina Gambung Propinsi Jawa
Barat dengan ketinggian tempat $1300 \mathrm{~m}$ di atas permukaan laut. Rancangan percobaan adalah Rancangan Acak Kelompok dengan empat ulangan. Perlakuan yang dicobakan adalah tujuh spesies jamur parasit G. rostochiensis yaitu Fusarium oxysporum TR1，F. solani TR2, F. oxysporum KT1, $F$. chlamydosporum KT2, $F$. oxysporum SM1, Paecilomyces lilacinus SM3, dan $F$. chlamydosporum SM4, dan satu perlakuan tanpa diinokulasi sebagai kontrol. Seluruh jamur parasit G. rostochiensis yang diisolasi dari tanah di beberapa areal pertanaman kentang di Propinsi Jawa Timur, Jawa Tengah, dan Jawa Barat. Sista G. rostochiensis diekstrasi dari tanah di Desa Sugih Mukti dan disterilisasi permukaan dengan larutan SLES 0,02 \% (Clovis dan Nolan, 1983).

Penyiapan Media Tanam, inokulasi jamur dan Penanaman Kentang

Sebagai media tanam digunakan campuran tanah Andisol asal Lembang dan kotoran ayam dengan perbandingan 3:1 (v/v) yang telah disterilkan. Sebanyak 1,75 kg media tanam dimasukkan ke dalam polibeg kemudian ditambahkan 50 sista. Sebanyak $100 \mathrm{~mL}$ suspensi jamur dengan kepadatan $10^{6}$ spora $\mathrm{mL}^{-1}$ diinokulasikan ke dalam $1,75 \mathrm{~kg}$ media tanam di dalam polibag (de Scurrah, 1981), kemudian diinkubasi di rumah kaca selama dua minggu. Selanjutnya media tanam ditanami dengan bibit kentang kultivar Granola F3 dan dipelihara di rumah kaca selama 8 minggu.

\section{Variabel Respons}

Pada minggu ke 8 setelah tanam diamati adalah tinggi dan bobot kering tajuk setelah pemanasan 70 ${ }^{\circ} \mathrm{C}$ selama dua hari serta serapan $\mathrm{P}$ dan $\mathrm{K}$ pada daun kentang menggunakan spektrometer. Data pengamatan dianalisis dengan analisis ragam dan uji lanjut dengan Uji Jarak Berganda Duncan (DMRT) pada $\alpha$ 0,10 (Johnson dan Bhattacharyya, 1996) menggunakan program SigmaStat 2.0.

\section{HASIL DAN PEMBAHASAN}

Inokulasi jamur uji, $F$. oxysporum TR1, F. solani TR2, F. oxysporum KT1, F. chlamydosporum KT2, F. oxysporum SM1, $P$. lilacinus SM3, dan $F$. chlamydosporum SM4 pada tanaman kentang yang ditanam pada media tanam terinfestasi sista $G$. rostochiensis, tidak menunjukkan gejala penyakit seperti daun menguning, kerdil atau layu dan busuk kering. Menurut Semangun, (2000), jamur dari genus 
Fusarium diketahui juga merupakan jamur patogen, penyebab penyakit busuk kering pada tanaman kentang, sehingga disimpulkan bahwa Fusarium yang dicobakan bukan merupakan jamur patogen, bahkan berpengaruh terhadap tinggi dan bobot kering tajuk serta serapan $\mathrm{N}$ dan $\mathrm{P}$ di daun kentang (Tabel 1 dan Tabel 2). tanaman yang diinokulasi $P$. lilacinus SM3. Peningkatan bobot kering tajuk serta serapan $\mathrm{P}$ dan $\mathrm{K}$ merupakan efek tidak langsung dari penghambatan perkembangan $G$. rostochiensis oleh jamur uji. Infeksi juvenil stadium dua (J2) $G$. rostochiensis pada akar kentang akan menginduksi terbentuknya tempat makan berupa sinsitium

Tabel 1. Pengaruh inokulasi jamur terhadap tinggi dan bobot kering tajuk tanaman kentang yang ditanam pada tanah terinfestasi sista $G$. rostochiensis.

\begin{tabular}{lcccc}
\hline \multirow{2}{*}{\multicolumn{1}{c}{ Spesies Jamur }} & \multicolumn{2}{c}{ Tinggi tajuk } & \multicolumn{2}{c}{ Bobot kering tajuk } \\
\cline { 2 - 5 } & $\begin{array}{c}\text { Tinggi } \\
(\mathrm{cm})\end{array}$ & $\begin{array}{c}\text { Peningkatan } \\
(\%)\end{array}$ & $\begin{array}{c}\text { Bobot } \\
(\mathrm{g})\end{array}$ & $\begin{array}{c}\text { Peningkatan } \\
(\%)\end{array}$ \\
\hline Tanpa jamur (Kontrol) & $28.68 \mathrm{a}^{*}$ & - & $4,94 \mathrm{a}^{*}$ & - \\
F. oxysporum TR1 & $29.95 \mathrm{a}$ & 4,45 & $6,60 \mathrm{e}$ & 33,60 \\
F. solani TR2 & $30.78 \mathrm{a}$ & 7,32 & $6,42 \mathrm{c}$ & 29,86 \\
F. oxysporum KT1 & $29.68 \mathrm{a}$ & 3,49 & $6,35 \mathrm{~b}$ & 28,44 \\
F. chlamydosporum KT2 & $31.28 \mathrm{a}$ & 9,07 & $6,46 \mathrm{~d}$ & 30,77 \\
F. oxysporum SM1 & $31.20 \mathrm{a}$ & 8,81 & $6,73 \mathrm{f}$ & 36,18 \\
P. lilacinus SM3 & $30.98 \mathrm{a}$ & 8,02 & $7,24 \mathrm{~h}$ & 46,46 \\
F. chlamydosporum SM4 & $31.93 \mathrm{a}$ & 11,33 & $7,23 \mathrm{~g}$ & 46,26 \\
\hline
\end{tabular}

Keterangan: *Angka yang diikuti oleh huruf yang sama pada satu kolom menunjukkan tidak berbeda pada level $10 \%$ dengan uji DMRT.

Tabel 2. Pengaruh inokulasi jamur terhadap serapan $\mathrm{P}$ dan $\mathrm{K}$ pada daun kentang yang ditanam pada tanah terinfestasi sista $G$. rostochiensis

\begin{tabular}{lcccc}
\hline \multirow{2}{*}{\multicolumn{1}{c}{ Spesies Namur }} & \multicolumn{2}{c}{ Serapan P pada daun } & \multicolumn{2}{c}{ Serapan K pada daun } \\
\cline { 2 - 5 } & $\begin{array}{r}\text { Jumlah } \\
\left(\mathrm{mg} \mathrm{g}^{-1}\right)\end{array}$ & $\begin{array}{c}\text { Peningkatan } \\
(\%)\end{array}$ & $\begin{array}{c}\text { Jumlah }(\mathrm{mg} \\
\left.\mathrm{g}^{-1}\right)\end{array}$ & $\begin{array}{c}\text { Peningkatan } \\
(\%)\end{array}$ \\
\hline Tanpa jamur (Kontrol) & $0,0103 \mathrm{a}^{*}$ & - & $0,0321 \mathrm{a}^{*}$ & - \\
F. oxysporum TR1 & $0,0134 \mathrm{~b}$ & 29,67 & $0,0489 \mathrm{c}$ & 52,43 \\
F. solani TR2 & $0,0145 \mathrm{c}$ & 40,88 & $0,0461 \mathrm{~b}$ & 43,88 \\
F. oxysporum KT1 & $0,0177 \mathrm{e}$ & 71,79 & $0,0567 \mathrm{~d}$ & 76,92 \\
F. chlamydosporum KT2 & $0,0164 \mathrm{~d}$ & 58,98 & $0,0580 \mathrm{e}$ & 81,01 \\
F. oxysporum SM1 & $0,0184 \mathrm{f}$ & 78,66 & $0,0591 \mathrm{f}$ & 75,02 \\
P. lilacinus SM3 & $0,0194 \mathrm{~h}$ & 87,88 & $0,0630 \mathrm{~h}$ & 96,57 \\
F. chlamydosporum SM4 & $0,0192 \mathrm{~g}$ & 86,74 & $0,0586 \mathrm{~g}$ & 82,67 \\
\hline
\end{tabular}

Keterangan: * Angka yang diikuti oleh huruf yang sama pada satu kolom menunjukkan tidak berbeda pada level $10 \%$ dengan uji DMRT.

Tabel 1 menunjukkan bahwa ketujuh jamur uji tidak meningkatkan tinggi tajuk, tetapi meningkatkan bobot kering tajuk sampai 28,44\% $46,46 \%$. Peningkatan tertinggi terjadi pada tanaman yang diinokulasi $F$. chlamydosporum SM3 dan $F$. chlamydosporum SM4 yaitu sekitar $46 \%$.

Inokulasi jamur uji juga meningkatkan serapan $\mathrm{P}$ dan $\mathrm{K}$ daun dengan nyata sampai masingmasing 29,67 \% - 87,88 \% dan 43,88 \% - 96,57\% (Tabel 2). Peningkatan tertinggi terjadi pada
(Hussey et al., 2002), sehingga terjadi perubahan fisiologi, morfologi, dan fungsi sel tanaman (Gheysen dan Fenoll, 2002).

Sinsitium dalam akar akan mempengaruhi penyerapan dan translokasi air dan unsur hara ke bagian tajuk. De Ruijter dan Haverkort, (1999) menjelaskan bahwa kandungan $\mathrm{N}, \mathrm{P}$ dan $\mathrm{K}$ daun pada tanaman yang terinfeksi Globodera spp secara umum berkurang. Trudgill et al., (1998) menambahkan bahwa infeksi J2 Globodera 
berpengaruh terhadap pertumbuhan akar kentang dan pada tingkat infeksi berat, sistem perakaran lebih sedikit karena berkurangnya jumlah akar lateral sehingga akar tidak efisien menyerap air dan hara. Fenomena di atas menyebabkan terganggunya proses fisiologis tanaman sehingga pertumbuhan dan bobot kering tanaman menurun.

Peningkatkan bobot kering tajuk, serapan $\mathrm{P}$ dan serapan pada daun setelah aplikasi $P$. lilacinus dapat disebabkan karena $P$. lilacinus menghasilkan sejumlah enzim yang berperan dalam degradasi bahan organik tanah. Sejumlah mikroorganisme ini berperan dalam siklus unsur hara di dalam tanah seperti siklus karbon, nitrogen dan fosforus (Atlas dan Bartha, 1993). Kotlova et al., (2007) menemukan senyawa serine proteinase ektraseluler pada filtrat medium kultur jamur P. lilacinus. Selanjutnya dikemukakan juga bahwa senyawa ini dapat menghidrolisis protein, gugus p-nitroanilide yang ada di tripeptida, dan norleucine, leucine dan phenylalanie. Gupta et al., (1993) mengemukakan bahwa $P$. lilacinus dapat memperlihatkan aktivitas enzim hidrolitik seperti polisakaridase, protease, dan kitinase. Degradasi substrat protein akan meningkatkan konsentrasi nitrogen tersedia di dalam tanah yang akan dimanfaatkan oleh tanaman bagi pertumbuhannya. Hidrolisis polisakarida di dalam tanah akan menghasilkan sumber karbon seperti gula sederhana dan asam organik untuk mikroorgnisme heterotrof. Dengan demikian secara tidak langsung, produksi enzim oleh $P$. lilacinus akan berperan dalam pertumbuhan tanaman.

\section{KESIMPULAN}

Inokulasi $F$. oxysporum TR1, $F$. solani TR2, $F$. oxysporum KT1, $F$. chlamydosporum KT2, $F$. oxysporum SM1, $P$. lilacinus SM3 dan $F$. chlamydosporum SM4 pada media tanam yang terinfestasi sista G. rostochiensis, tidak menimbulkan penyakit bahkan dengan nyata meningkatkan bobot kering tajuk serta serapan $\mathrm{P}$ dan $\mathrm{K}$ pada pada tanaman kentang.

\section{UCAPAN TERIMAKASIH}

Kami berterimakasih kepada Kepala Balai Pengawasan dan Sertifikasi Benih Tanaman Pangan dan Hortikultura Propinsi Jawa Barat dan Kepala Pusat Penelitian Teh dan Kina, Gambung, Kabupaten Bandung Jawa Barat atas kesediaan memberikan ijin penggunaan fasilitas di
Laboratorium dan Rumah Kaca untuk pelaksanaan penelitian.

\section{DAFTAR PUSTAKA}

Atlas, RM and R Bartha. 1993. Microbial Ecology. Third Edition. Canada: The Benjamin/Cummings Publishing Company, Inc.

Clovis, CJ and RA Nolan. 1983. Fungi associeted with cysts, eggs and juveniles of the golden nematodes (Globodera rostochiensis) in Newfaoundland. Nematologia 29: 245-365.

DAFFA (Departmen of Agriculture, Fisheries and Forestry Australia). 2003. Potato cyst nematode. Melalui $<$ http://www.affa.gov.au/content/ schools/rl/8071.htm $>$ [14/10/03].

Daryanto, 2003. Status penyebaran dan kerugian nematoda sista kuning pada tanaman kentang. Makalah disampaikan pada Lokakarya Nematoda Sista Kuning. Yogyakarta, 11-12 Desember 2003.

de Ruijter, FJ and AJ Haverkort. 1999. Effects of potatos-cyst nematode (Globodera pallida) and soil $\mathrm{pH}$ on root growth, nutrient uptake and crop growth of potato. Europan Journal of Plant Pathology 105: 61-76.

Evans, K., R. Webster, A. Barker, P. Halford, and R. Russell. 2003. Mapping Infestation of Potatos Cyst Nematodes and the Potential for Spatially Varying Application of Nematicides. Herts: IACR-Rothamsted, Harpenden, UK.

Gheysen, G. and C. Fenoll. 2002. Gene expression in nematode feeding sites. Annu. Rev. Phytopathol. 40: 124-168.

Gupta, V.V.S.R. and G.W. Yeates. 1998. Soil Microfauna as Bioindicators of Soil Health. In Pankhurst. C., B.M. Doube, and V.V.S.R. Gupta (eds). Biological Indicators of Soil Health, 201-233 pp. New York: CAB International

Hussey, R.S., E.L. David, and T.J. Baum. 2002. Secrets in secretions: Genes that control nematode parasit of plants. Braz J. Plant Physiol. 14: 183-194.

IPC (International Potato Center), 2002. Nematodes. Potato Cyst Nematodes. Peru - Lima.

Jaffee, B.A., H. Ferris, and K.M. Scow. 1998. Nematode-trapping fungi in organic and 
conventional trapping systems. Phytopathology 88: 244-350.

Jatala, P. and J. Bridge. 1995. Nematoda Parasitik pada Tanaman Akar dan Ubi-Ubian. Dalam Luc.M., R.A. Sikora, dan J. Bridge, J (penyunting). Nematoda Parasitik Tumbuhan, halaman 176-185. Yogyakarta: Gadjah Mada University Press.

Johnson, R.A. and G.K. Bhattacharyya. 1996. Statistik: Prinsiples and Methodes. Third Edition. Canada: John Willey and Sons, Inc.

Kalay. A.M, S. Natasasmita, T. Suganda, dan T. Simarmata. 2008. Uji Parasitik Beberapa Spesies Jamur Tanah terhadap Globodera rostochiensis (Woll) Secara In Vitro. Jurnal Natur Indonesia 10: 73-75.

Kotlova, E., N. Ivanova., M. Yusupova., T. Voyushina., N. Ivanushkina, and G. Chestukhina. 2007. Thiol-dependent serine proteinase from Paecilomyces lilacinus. Purification and catalytic properties. Biochemintry 72: 117-123.

Lisnawita. 2007. Identifikasi, Kajian Biologi, Evaluasi Ketahanan Tanaman dan Kisaran Inang Nematoda Sista Kentang (Globodera spp) Indonesia. Bogor: Disertasi Institut Pertanian Bagor.

Sanchesz-Bayo, F., S. Baskaran, and I.B. Kennedy. 2002. Ecological relative risk (EcoRR): Another approach for risk assessment of pesticides in agriculture. Agricultura, Ecosystems and Environment 91: 37-57.

Semangun, H. 2000. Penyakit-penyakit Tanaman Hortikultura di Indonesia. Yogyakarta: Gadjah Mada University Press.

Trudgill, D.L., K. Evans, and M.S. Philips. 1998. Potato Cyst Nematodes: Damage, Mechanisme and Tolerance in the Potatos. In Marks, R.J. and B.B. Brodie (eds). Potato Cyst Nematodes : Biology, Distribution and Control, 7-26 pp. New York: CAB International.

Turner, S.J. and K. Evans. 1998. The Original, Global Distribution and Biology of PCN (Globodera rostochiensis (WoLL) and Globodera pallida (Stone). In Marks, R.J. and B.B. Brodie (eds). Potato Cyst Nematodes : Biology, Distribution and Control, hlm 7-26. New York: CAB International. 